\title{
REVIEW
}

\section{Identifying thyroid stem/progenitor cells: advances and limitations}

\author{
Alessandra Fierabracci \\ Research Laboratories, Ospedale Pediatrico Bambino Gesù Research Institute, Children's Hospital Bambino Gesù, Piazza S. Onofrio, 4, 00165 Rome, Italy \\ (Correspondence should be addressed to A Fierabracci; Email: fierabracci@opbg.net; alefierabracci@hotmail.it)
}

\begin{abstract}
Continuing advances in stem cell science have prompted researchers to envisage the potential application of stem cells for the management of several debilitating disorders, thus raising the expectations of transplant clinicians. In particular, in order to find a source of adult stem cells alternative to embryonic stem cells (ESCs) for the exploration of novel strategies in regenerative medicine, researchers have attempted to identify and characterise adult stem/progenitor cells resident in compact organs, since these populations appear to be responsible for physiological tissue renewal and regeneration after injury. In particular, recent studies have also reported evidence for the existence of adult stem/progenitor cell populations in both mouse and human thyroids. Here,
\end{abstract}

I provide a review of published findings about ESC lines capable of generating thyroid follicular cells, thyroid somatic stem cells and cancer stem cells within the thyroid. The three subjects are analysed by also considering the criticism recently raised against their existence and potential utility. I comment specifically on the significance of resident thyroid stem cells in the developmental biology of the gland and their putative role in the pathogenesis of thyroid disorders and on the protocols employed for their identification. I finally provide my opinion on whether from basic science results obtained to date it is possible to extrapolate any convincing basic for future treatment of thyroid disorders.

Journal of Endocrinology (2012) 213, 1-13

\section{Introduction}

Recent discoveries in stem cell research both in vitro and in vivo have opened new pathways for understanding many of the physiological mechanisms controlling basic biological processes as well as disease mechanisms. Although several ethical concerns have been raised regarding the use of stem cells in regenerative medicine, stem cell research has nevertheless opened new routes in the field of medical practice, resulting in powerful new therapeutic options and drug discoveries (Daley 2010).

The scientific community nowadays recognises mainly two types of stem cells: the embryonic stem cell (ESC) and the somatic stem cell (SSC). Both are defined as clonogenic populations with a capacity for self-renewal and immortality (i.e. extended lifespan or a number of possible divisions; Maenhaut et al. 2010). Stem cells are capable of asymmetric cell division; this implies that throughout an irreversible, deterministic process, they sequentially generate a qualitatively different hierarchy of differentiated cells with little or no reproductive capacity, reflecting the cell heterogeneity within tissues. Meanwhile, some symmetrical divisions occur that generate two stem cells, thus ensuring homeostatic control (Maenhaut et al. 2010). There are also important differences between ESCs and SSCs. ESCs can generate all three germ layers and finally all differentiated cells. Instead, SSCs resident in compact organs have a more restricted differentiation potential, showing plasticity and the capacity to produce mature cells of the tissue of origin, but sometimes also to transdifferentiate towards multiple specialised cell types (Li \& Clevers 2010). ESCs reproduce rapidly, and to maintain their undifferentiated state these cells simply need to be protected from differentiating agents. Instead, the division rate of SSCs appear to be low, although this fact has raised controversies (Maenhaut et al. 2010), and to maintain their undifferentiated state these cells need to be protected in a specific microenvironment: the niche (Morrison \& Spradling 2008). The specific molecular and functional features of SSCs often remain unknown because of their rarity and the technical difficulties involved in identifying them and characterising their progeny (Gritti et al. 1996, Nunes et al. 2003, Alessandri et al. 2004, Messina et al. 2004, Fierabracci et al. 2007, 2008, Puglisi et al. 2008, Burger et al. 2009, Maiorana et al. 2009, Houbracken \& Bouwens 2010, Bertoncello \& McQualter 2011, Hicok \& Hedrick 2011, Tanaka et al. 2011). It is generally recognised that resident 
adult stem cells appear to be responsible for maintaining tissue homeostasis and for regeneration of the organ after damage (Li \& Clevers 2010).

The evidence provided for the role of stem cells in embryogenesis and in the self-renewal and homeostasis of adult tissues, especially haematopoietic, has led researchers to hypothesise the putative role of a similar population of stem cells at the origin of tumours and to develop the 'cancer stem cell (CSC) theory' (Lin 2007). Stem cells of cancer are also recognised as tumour-initiating cells (TICs) or stemloids (Maenhaut et al. 2010). The 'CSC theory' has already been proposed in the literature to envisage the development of novel therapeutic approaches aimed at the eradication of tumour cells.

Compared with other organs and tissues, resident adult stem cells of the human thyroid have been insufficiently studied for a long time because hypothyroid patients can be adequately treated with the available, well-standardised laevo-thyroxine therapy. This synthetic hormone faithfully reproduces the physiology of the molecule secreted by the gland that is necessary for the growth and metabolism of each cell type in the organism (Beck-Peccoz et al. 2004). Regarding this latest issue, Lin et al. (2003) initially provided evidence for the possibility of differentiating mouse ESCs into thyrocyte-like cells in vitro. More recently, remarkable achievements in stem cell biology have provided evidence for the presence of adult stem/progenitor cell populations (resident SSCs) within the human and mouse thyroid (Thomas et al. 2006, 2008, Hoshi et al. 2007, Lan et al. 2007, Fierabracci et al. 2008), implying their role in pathophysiology. Data were also published regarding the identification of stem cells in thyroid tumours (CSCs) as the initiator population.

In this review, I therefore provide an in-depth analysis of the three subjects, comparing the morphological and functional characteristics of ESCs, SSCs and CSSs, summarising research that support the role of resident stem cells in the physiology and pathophysiology of different thyroid disorders, as well as highlighting the criticism and the debate raised against their existence and function. I finally try to answer one of the most important questions for the scientific community related to this subject: whether from basic science results obtained on thyroid stem/progenitor cells to date it is possible to extrapolate any convincing basis for the management of thyroid disorders.

\section{ESCs as a source of thyrocytes}

Lin et al. (2003) first investigated the possibility of generating thyroid hormone-secreting cell lines by the differentiation of mouse ESCs. Of importance, the process of embryoid body development resulted in the appearance of paired box gene 8 $(P A X 8)$ and thyroid stimulating hormone receptor (TSH-R), which were under the influence of the main trophic thyroid regulator, TSH. The study presented a powerful model for the study of thyrocyte developmental diseases.
Arufe et al. (2006) used a strategy of differentiation where, with the support of Matrigel, highly enriched ESCs formed thyroid follicle-like clusters in a serum-free differentiation medium supplemented with TSH. Putative thyroid follicular cells accounted for only a small percentage $(\sim 1 \%)$ of differentiated ESCs. More recent studies clearly indicated that TSH is important for the induction and specification of thyrocytes from ESCs, while insulin-like growth factor 1 (IGF1) and insulin are crucial factors for thyrocyte maturation (Arufe et al. 2009).

Remarkably, with activin A alone, a member of the transforming growth factor $\beta$ superfamily, thyroid endoderm could be differentiated from ESC (Arufe et al. 2009); a small proportion of cells expressing PAX8 and TSH-R and the sodium iodide symporter (NIS) were produced without the addition of TSH or IGF1 (TSH-independent induction; Ma et al. 2009, Davies et al. 2011).

In a recent investigation, Jiang et al. (2010) (reviewed in Lin \& Davies (2010)) used the mouse E14 ESC line to confirm the feasibility of inducing differentiation into thyrocytes by adding TSH and insulin. They again detected thyroid transcription factors PAX8 and thyroid transcription factor 1 (TTF1), but their timing of expression and even that of thyroid-specific genes remains to be. They did, however, provide the first demonstration of TTF1 protein in ESC-derived thyrocytes. However, newly generated thyrocytes failed to produce thyroid hormones, suggesting that the real number of successfully differentiated cells remains to be unravelled.

\section{Adult thyroid stem/progenitor cells}

\section{Evidence for resident stem cells in the normal thyroid and its benign pathology}

Doniach (1974) first hypothesised that the thyroid is a low proliferating organ (vide infra) where follicular cells divide only a few times during a lifetime, four or five times prior to adulthood in humans, and do not divide afterwards (Coclet et al. 1989). Throughout this slow cell turnover (estimated at 8.5-14.4 years), the gland is able to maintain its size in physiological conditions (Coclet et al. 1989). The thyroid gland is, therefore, capable of self-renewal and, based on indirect evidence, the hypothesis of the existence of a population of resident thyroid stem cells was first put forward by Dumont et al. (1992). For example, following the injection of a low number of cells, growth of thyroid transplants indeed occurred in recipient animals (Mulcahi et al. 1980). Accordingly, radiobiological cloning experiments demonstrated that foci generation could develop but with very low efficiency. These experiments were clearly indicative of the theoretical number of stem cells within the gland, estimated to be about 1:1000 (Dumont et al. 1992). Other evidence was subsequently provided for the existence of thyroid stem cells, as summarised below. 
Embryological remnants Takano (2004) already proposed the hypothesis that thyroid cancer cells are derived from the remnants of foetal thyroid cells instead of thyrocytes. A stem cell origin was initially suggested for embryological remnants known as solid cell nests of the thyroid (Reis-Filho et al. 2003, Rios Moreno et al. 2010). They are postulated to be derived from the ultimobranchial body and the thyroid diverticulum (Klonisch et al. 2009). These structures are composed of two distinct cell types: main cells and parafollicular cells or calcitonin (CT)-producing C cells (Fierabracci et al. 1993). On histopathological examination, their typical features are not easy to distinguish from squamous metaplasia or carcinomas, thyroglossal cysts and C-cell hyperplasia (Gibson et al. 1982, Baschieri et al. 1989). In the light of the aforementioned, Gibelli et al. (2009) has hypothesised that three types of stem cells are present in the thyroid gland: the progenitor of follicular cells (Dumont $e t$ al. 1992) of endodermal origin, the progenitor of C cells (Gibson et al. 1982, Fierabracci et al. 1993) derived from the neural crest, and bipotential progenitors of both follicular and C cells (Gibelli et al. 2009). Reis-Filho et al. (2003) (reviewed in Burstein et al. (2004)) first introduced the idea that the 'main' cells of solid cell nests, expressing the basal/stem cell marker p63, while negative for terminal thyroid differentiation markers such as thyroglobulin (TG) of thyrocytes and CT of parafollicular cells, would be the real thyroid stem cells; these elements are found in solid cell nests often admixed with separate regular follicular cells lining a follicular lumen. This hypothesis, put forward by different authors, certainly deserves to be further explored. The p63 population of cells has been demonstrated to possess some stem cell properties, including a capacity of self-renewal and the ability to differentiate into more than one cell type (Cameselle-Teijeiro et al. 1995).

Microchimerism Another source of stem/progenitor cells was suggested to derive from foetal-maternal bidirectional trafficking of cells, a phenomenon occurring in almost all placental species (Liegeois et al. 1977). The presence of allogenic foetal cells in maternal tissues is also known as microchimerism (Klintschar et al. 2001, Srivatsa et al. 2001, Koopmans et al. 2008, Klonisch et al. 2009). At the end of pregnancy, foetal cells have been demonstrated in the peripheral blood of mothers (Srivatsa et al. 2001) and the persistence of foetal cells was also reported in maternal tissues. According to a recent hypothesis (Srivatsa et al. 2001), longterm survival of male foetal cells would lead to the generation of autoimmune responses.

\section{Stem/progenitor cells derived from bone marrow It has also been suggested that in many high- and low- proliferating organs, stem/progenitor cells are furnished by bone marrow (Sherwood et al. 2004, Klonisch et al. 2009). According to Cohen et al. (2007) and Sanders et al. (2009), this phenomenon could be responsible for the increased risk}

of secondary thyroid carcinoma observed in patients who have received haematopoietic stem cell transplantation.

\section{Resident adult stem/progenitor cells}

Identifying adult stem/progenitor cells in the murine thyroid The first attempts to isolate adult/stem progenitor cells were performed on the mouse thyroid (Hoshi et al. 2007, Lin 2007). Previous experience had shown that a side population (SP) of cells could be selected in the adult mouse bone marrow from the main cell population (MP) as a distinct subset based on its ability to efflux the vital dye Hoechst 33342; the cells were incubated with the dye and then analysed by fluorescence-activating cell sorter (FACS) analysis (Goodell et al. 1996). It was subsequently proven that the expression of ATP-binding cassette-dependent transporter ABCG2 (Thomas et al. 2008) was responsible for this property and for making the dye efflux of SP cells sensitive to verapamil (Zhou et al. 2001). SP cells were recognised to have features consistent with stem cells since, when identified in nonhaematopoietic tissues such as liver and muscle (Gussoni et al. 1999, Hussain et al. 2005), these elements were able to contribute to tissue regeneration. In the isolation procedure performed by Hoshi et al. (2007), a single cell suspension of thyroid follicles was obtained by a two-step enzymatic digestion. Dissociated thyroid cells from 4- to 5-week-old mice were then stained with Hoechst 33342. FACS analysis produced a small but distinct population of Hoechst-effluxing cells $(0 \cdot 3-1 \cdot 4 \%$ of the total cells). In a subsequent step, this population was further characterised for the expression of CD45 marker to distinguish haematopoietic $\mathrm{CD} 45^{+}$from non-haematopoietic (thyroid) $\mathrm{CD}^{-} 5^{-}$cells (Shivtiel et al. 2008). Two other markers expressed in murine haematopoietic stem cells were also tested: the stem cell antigen-1 (SCA1) and the receptor tyrosine kinase c-KIT (van de Rijn et al. 1989, Edling \& Hallberg 2007). Finally, the authors (Hoshi et al. 2007) demonstrated that the SP fraction in the mouse thyroid was composed of two sub-populations of cells: CD45(-)/c-KIT (-)/SCA1 (+) and CD45 (-)/c-KIT $(-) /$ SCA1 $(-)$ cells. The SP cells were also sorted based on SCA1 expression. Thyroid SP cells were further subfractionated in SP1 and SP2 cells based on the level of Hoechst efflux, implying that with stronger dye efflux ability, higher stem/progenitor activity may exist. Approximately the same degree of SCA1-positive cells was obtained within the SP1 and SP2 fraction. The thyroid SP cells were further investigated in molecular studies. Quantitative RT-PCR analysis revealed that the $A B C G 2$ gene was similarly expressed in both SP1 and SP2 cells. Nucleostemin (Tsai \& Meng 2009) was highly expressed in SP1, whereas octamerbinding transcription factor 4 (OCT4) expression was detected in both SP fractions and not significantly expressed in MP cells. Thyroid-specific genes, in particular thyroperoxidase (TPO) and TG, were highly expressed in MP cells, followed by SP2 and SP1 cells. Weak expression of TTF1 (Guazzi et al. 1990, De Felice \& Di Lauro 2004) and TSH-R 
was detected in the SP2 fraction; this led to envisage the possible role of the two genes in the commitment and maintenance of the thyroid lineage.

Localisation of ABCG2-expressing cells in the thyroid gland was determined using nonisotopic in situ hybridisation and immunofluorescence. ABCG2 expression was detected only in a small number of cells in the interfollicular space, but not in cells lining the follicles. On the basis of gene expression analysis, the authors concluded that thyroid SP cells, and in particular SP1 cells, are less differentiated and have characteristics of stem/progenitor cells.

Identifying adult stem/progenitor cells in the human thyroid In recent years, remarkable achievements in stem cell biology have led to the identification and characterisation of resident adult stem/progenitor cells in human goitres. Thomas et al. (2006) first provided evidence for adult stem and precursor cells of endodermal origin in the human thyroid glands by investigating the expression of the stem cell marker OCT4 and the early endodermal markers GATA binding protein 4 (GATA4) and hepatocyte nuclear factor $4 \alpha(\mathrm{HNF} 4 \alpha)$ in histological slides and cultured cells derived from goitres, in the FRTL5 murine cell line and in thyroid carcinoma cell lines. It is well known that thyroid follicular cells are derived from the endoderm (Di Lauro \& De Felice 2001), that GATA4 expression increases when ESCs differentiate into endoderm (Zhang et al. 2007), and that HNF4 $\alpha$ is expressed early in endoderm formation (Kanazawa et al. 2009). Stem cell markers were detectable in all primary cultures; on the contrary, no expression was revealed in the differentiated FRTL5 line. TSH stimulation did not affect the expression of the stem cell marker mRNA. Immunohistochemical examination of cultured cells and of tissue sections from goitres revealed single cells positive for OCT4, GATA4 and HFN4 $\alpha$, therefore identified as progenitors, while being negative for TG expression. Cells were dispersed within follicles, without the evidence for a niche. Expression of OCT4 but not of GATA4 was also detected in some thyroid carcinoma cell lines. By FACS sorting of cultured cells, a small number of OCT4-, GATA4- and HFN4 $\alpha$-positive cells were isolated. Co-localisation studies in double stainings revealed a large population of TG-positive but OCT4-negative cells and a small population of OCT4-positive but TG-negative cells. Increasing the concentration of TSH in the culture medium did not affect the percentage of OCT4-positive cells as revealed by FACS analysis.

Lan et al. (2007) established monolayer cultures of human thyrocytes from nodular goitres. From these cultures, adult stem cells were isolated as SP by FACS from differentiated thyrocytes and endodermal marker-positive cells due to their ability to express the specific marker of embryonic and adult stem cells ABCG2 (Thomas et al. 2006, 2008, Hoshi et al. 2007, Lan et al. 2007, Lin 2007). SP-gated cells accounted for about $0 \cdot 1 \%$ of total cells. Semiquantitative RT-PCR analysis demonstrated that SP cells expressed ABCG2 and the stem cell marker OCT4 but were negative for thyroid differentiation markers TG, TPO, TSH-R and NIS. Non-SP cells expressed instead all the thyroid differentiation markers as well as PAX8 (Pasca di Magliano et al. 2000), which is crucial in early stages of thyroid development. SP cells were FACS sorted by the Hoechst 33342 efflux technique and cultured in the presence of epidermal growth factor (EGF) and basic fibroblast growth factor (bFGF). Intense growth stimulation was produced by co-culture with thyrocytes; this resulted in the formation of non-adherent three-dimensional (3D) spheres (thyrospheres) since 5 days of culture. No sphere was observed in the presence of serum and TSH. 5-Bromo- $2^{\prime}$-deoxyuridine $(\mathrm{BrdU})$ incorporation experiments demonstrated that thyrospheres grew in size by stem cell division. Even in this study, in RT-PCR, cells from thyrospheres expressed the stem cell marker OCT4, ABCG2, and the endodermal markers GATA4 and HNF4 $\alpha$ but were negative for thyroid differentiation markers PAX8, TG, NIS, TSH-R and TPO. On the first day of culture, sphere cells did not express TSH-R transcripts. On FACS analysis, growth factor-stimulated cells contained an increased SP population than in primary thyroid cultures up to $5 \%$ of stem cells. After 3 days in the presence of serum TSH-R started to be expressed at low levels. With the addition of TSH for an additional 18 days, TSH-R expression gradually increased from days 3 to 21 . Afterwards, cells from thyrospheres produced thyrocytes expressing PAX8 and all the typical thyroid differentiation markers, but almost no stem cells or endodermal markers. Analysis of cell proliferation demonstrated that sphere cells proliferated rapidly during the first 3-4 days of sphere formation in response to intense growth stimulation and that proliferation slowed down on day 5. Conversely, upon stimulation with TSH and serumenriched medium, sphere-derived cells behaved as primary cultured thyrocytes. In addition, when embedded in 3D collagen gels, differentiated cells showed TSH-dependent 125 iodide uptake; no evidence was provided for the generation of thyroid follicles. No data from long-term culture experiments were reported in this study and no evidence for the clonogenicity of single cells in vitro and the possibility of multi-lineage differentiation in vitro was provided, elements which are critical for the recognition of a tissue-specific adult stem cell.

In my laboratory, spheroids with self-replicative potential were obtained from normal glands and affected with benign pathology (Fierabracci et al. 2008). Cells were isolated by enzymatic digestion of fresh thyroid tissue and cultured in a special 'spheroid medium' containing EGF and bFGF. Within 7-10 days of culture, few residual differentiated cells remained attached to the bottom of the culture dish. Meanwhile, small primary clusters of cells appeared floating in the supernatant, started to proliferate and became increasingly more numerous, with a 'spheroid-like' structure (thyrospheres). Lines of spheroids were generated that could be maintained in the culture for an average time of 2 months. Of importance, clonogenesis experiments demonstrated that spheroids generated from the thyroid specimens were 
found to be composed of clonally derived cells and did not simply represent cellular aggregates. Thyrospheres were analysed by immunocytochemistry on cytospun slides and in FACS analysis. The isolated stem/progenitor cell population contained a subset of CD $34^{+} \mathrm{CD} 45^{-}$cells; a small number of cells, variable from one generated line to the other, expressed TG and TPO, whilst being constantly negative for TSH-R and NIS expression. It would have been interesting to show whether TG and TPO were co-localised in the same cells, or whether CD34 was co-localised with the other thyroid differentiation markers. Nevertheless, similar experiments could not be performed, because monoclonal antibodies (MoAbs), directly conjugated with different fluorochromes, directed against these thyroid differentiation markers, are not commercially available. It is relevant to underline the expression at the mRNA level of nestin and pluripotency markers OCT4 and NANOG (Chambers et al. 2003) in all the lines examined. In differentiation conditions (i.e. 3D collagen gel cultures in the presence of differentiation medium lacking EGF and bFGF, but in the presence of serum), the population was able to generate follicles with typical thyroid hormone production. In immunocytochemistry, cells within follicles were all positive for TG, while TPO positivity was more evident in cells placed at the periphery of the follicles. The expression of TSH-R was not detectable. When freshly isolated spheroids were co-cultured with a neuroblastoma cell line, they generated cells expressing the neuronal marker $\beta$-tubulin III. Spheroids were also able to differentiate towards the adipogenic phenotype when cultured in adipogenic medium. Thyrospheres were not tumourigenic when injected into SCID (severe combined immunodeficiency) mice.

\section{Are thyroid stem/progenitor cells really necessary in normal physiology and pathophysiology?}

All the evidence reported so far (vide supra) simply supports the presence of thyroid stem/progenitor cells within the normal human thyroid. Nevertheless, to date, multi-potent stem cells identified by 'unique' markers have not been isolated from the human thyroid (Tables 1 and 2) and there is no obvious consensus on the method employed for their isolation and identification. I agree with recently raised criticism (Prof. JE Dumont, International Thyroid Meeting, Paris 11-16 September 2010 and personal communication) that, in published articles, sometimes there is not a clear definition of the protocols employed and the results obtained after each step. It remains possible to speculate that thyroid stem/progenitor cells divide by asymmetric cell division, giving rise to two daughter cells: one identical to the mother cell and the other belonging to a stem cell compartment of differentiating committed progenitor cells. As suggested by the immunophenotypic characteristics of single elements within thyrospheres (Fierabracci et al. 2008), these would start to progressively acquire typical phenotypic markers of differentiation and finally reach the adult cell type.

Table 1 Putative stem/progenitor markers and thyroid differentiation markers analysed in the normal human thyroid and its benign pathological conditions

\begin{tabular}{|c|c|c|c|}
\hline $\begin{array}{l}\text { Putative stem/progenitor } \\
\text { cell marker }\end{array}$ & Thyroid differentiation marker & Source of cells & References \\
\hline $\begin{array}{l}\text { OCT4 } \operatorname{pos}^{\mathrm{a}, \mathrm{b}} \\
\text { GATA4 } \operatorname{pos}^{\mathrm{a}, \mathrm{b}} \\
\text { HNF4a pos } \\
\text { PAX8 } \operatorname{pos}^{\mathrm{b}}\end{array}$ & Tg neg ${ }^{a, b}$ & Human goitre & Thomas et al. (2006) \\
\hline $\begin{array}{l}\text { ABCG2 } \text { pos }^{a} ; \text { SP pos }{ }^{a} \\
\text { OCT4 pos }{ }^{b} \text { SP pos }{ }^{a} \\
\text { GATA4 pos }{ }^{b} \text { non-SP } \\
\text { HNF4a pos }{ }^{\text {b }} \text {, non-SP } \\
\text { PAX8 pos }{ }^{\text {b }} \text {; non-SP }\end{array}$ & $\begin{array}{l}\text { TG neg; TSH-R neg; NIS neg; } \\
\text { TPO neg } \\
\text { TG pos; TSH-R pos; NIS pos; } \\
\text { TPO pos }{ }^{\text {a }}\end{array}$ & $\begin{array}{l}\text { Cells from human goitre grown as } \\
\text { thyrospheres }\end{array}$ & Lan et al. (2007) \\
\hline $\begin{array}{l}\text { OCT4 pos }{ }^{b} \\
\text { NANOG pos } \\
\text { Nestin pos }{ }^{\mathrm{b}} \\
\text { Nestin neg } \\
\text { CD34 pos } \\
\text { CD45 neg, } \text { ne }^{\mathrm{a}, \mathrm{b}}\end{array}$ & $\begin{array}{l}\text { TG pos, TPO pos; NIS neg; } \\
\text { TSH-R neg } \\
\text { (variable percentages of positive } \\
\quad \text { cells in different thyrosphere lines) }\end{array}$ & $\begin{array}{l}\text { Thyrospheres grown from normal } \\
\text { and benign pathological conditions }\end{array}$ & Fierabracci et al. (2008) \\
\hline $\begin{array}{l}\text { OCT4 pos } \\
\text { ABCG2 } \\
\text { SOX2 } \\
\text { NANOG }^{b} \\
\text { CD133 }^{b}\end{array}$ & TG, TPO, TSH-R & Benign goitre & Malaguarnera et al. (2010) \\
\hline
\end{tabular}

Pos, positive; Neg, negative.

anvestigation/s carried out by FACS analysis.

b Investigation/s carried out by RT-PCR. 
Table 2 Identified populations of adult stem cells and/or progenitor cells in the human thyroid, their proliferative capacity, clonogenic properties, ability to differentiate into thyrocytes, transdifferentiation capacity and to ability induce tumour formation in vivo

\begin{tabular}{|c|c|c|c|c|c|}
\hline $\begin{array}{l}\text { Characteristic of the } \\
\text { identified population }\end{array}$ & Proliferative capacity & $\begin{array}{l}\text { Clonogenic } \\
\text { properties }\end{array}$ & $\begin{array}{l}\text { Differentiation } \\
\text { into thyrocytes }\end{array}$ & $\begin{array}{l}\text { Transdifferentiation } \\
\text { capacity }\end{array}$ & $\begin{array}{l}\text { Teratoma } \\
\text { formation } \\
\text { in vivo }\end{array}$ \\
\hline $\begin{array}{l}\text { Quiescent adult stem cells in } \\
\text { benign human goitre } \\
\text { (Lan et al. 2007) }\end{array}$ & $\begin{array}{l}\text { Present and detected by } \\
\text { 5-bromo- } 2^{\prime} \text { incorporation } \\
\text { in thyrosphere cells }\end{array}$ & Not tested & $\begin{array}{l}\text { Ability to } \\
\text { differentiate into } \\
\text { thyroid cells }\end{array}$ & Not tested & Not tested \\
\hline $\begin{array}{l}\text { Stem/progenitor cells in } \\
\text { normal thyroid and benign } \\
\text { pathology } \\
\text { (Fierabracci et al. 2008) }\end{array}$ & $\begin{array}{l}\text { Demonstrated by serial halv- } \\
\text { ing of carboxyfluorescein } \\
\text { diacetate succinimidyl } \\
\text { ester (CFDE) }\end{array}$ & $\begin{array}{l}\text { Assessed from single } \\
\text { CFDE-positive } \\
\text { cells }\end{array}$ & $\begin{array}{l}\text { Ability to differ- } \\
\text { entiate in 3D } \\
\text { collagen gels }\end{array}$ & $\begin{array}{l}\text { Verified towards } \\
\text { neurogenic and } \\
\text { adipogenic } \\
\text { phenotype }\end{array}$ & $\begin{array}{l}\text { No tumour } \\
\text { formation }\end{array}$ \\
\hline $\begin{array}{l}\text { Cancer stem-like cells in } \\
\text { human ATC } \\
\text { (Friedman et al. 2009) }\end{array}$ & $\begin{array}{l}\text { Assessed in cell proliferation } \\
\text { colorimetric assay }\end{array}$ & Not tested & Not tested & Not tested & $\begin{array}{l}\text { Highly } \\
\text { tumourigenic }\end{array}$ \\
\hline $\begin{array}{l}\text { Cancer stem-like cells in SP } \\
\text { population of ATC lines } \\
\text { (Mitsutake et al. 2007) }\end{array}$ & $\begin{array}{l}\text { Assessed in cell proliferation } \\
\text { assay }\end{array}$ & $\begin{array}{l}\text { Higher clonogenic } \\
\text { ability of sorted SP } \\
\text { cells }\end{array}$ & Not tested & Not tested & $\begin{array}{l}\text { Tumour } \\
\text { formation }\end{array}$ \\
\hline $\begin{array}{l}\text { Cancer stem-like cells in } \\
\text { human ATC (Zito et al. } \\
\text { 2008) }\end{array}$ & $\begin{array}{l}\text { Assessed in cell } \\
\text { proliferation colorimetric } \\
\text { assay }\end{array}$ & $\begin{array}{l}\text { Assessed in colony } \\
\text { forming assay }\end{array}$ & Not tested & Not tested & Not tested \\
\hline $\begin{array}{l}\text { Cancer stem-like cells in } \\
\text { MTC lines } \\
\text { (Zhu et al. 2010) }\end{array}$ & $\begin{array}{l}\text { Demonstrated by limiting } \\
\text { dilution assay }\end{array}$ & $\begin{array}{l}\text { Rederivation } \\
\text { experiments in } \\
\text { growth assay }\end{array}$ & Not tested & Not tested & Not tested \\
\hline $\begin{array}{l}\text { Cancer stem cells (Todaro } \\
\text { et al. 2010) }\end{array}$ & $\begin{array}{l}\text { Demonstrated in clonogenic } \\
\text { experiments performed } \\
\text { by limiting dilution }\end{array}$ & & Not tested & Not tested & $\begin{array}{l}\text { Tumour } \\
\text { formation }\end{array}$ \\
\hline $\begin{array}{l}\text { Normal and cancer stem/- } \\
\text { progenitor cells (PTC; } \\
\text { Malaguarnera 2011) }\end{array}$ & $\begin{array}{l}\text { Sphere size is used for } \\
\text { evaluating cell } \\
\text { proliferation and growth }\end{array}$ & Not tested & Not tested & Not tested & Not tested \\
\hline
\end{tabular}

Nevertheless, a few arguments were recently addressed against a putative role of thyroid stem cells in thyroid physiology and benign pathophysiology (Prof. JE Dumont, International Thyroid Meeting, Paris 11-16 September 2010 and personal communication). First of all, it is remarkable to observe that in the human body, there are high- and lowproliferating organs with high and low cell turnover respectively. The stem cell compartment is usually well limited in highly proliferating tissues. In citing examples, the mammalian intestine is covered by a single layer (van der Flier \& Clevers 2009) of epithelial cells that is fast renewed every 4-5 days. As the function of stem cells is to maintain the integrity of the intestinal epithelium, it must self-renew, proliferate and differentiate within a protective well-limited niche, which comprises both extrinsic and intrinsic signals that govern cell fate (Yen \& Wright 2006). The niche is made up of proliferating and differentiating epithelial cells and surrounding mesenchymal cells. These mesenchymal cells promote the epithelial-mesenchymal cross talk required to maintain the niche. Both quiescent (out of cell cycle in a low metabolic state) and active (in cell cycle and not able to retain DNA labels) stem cell populations would coexist under the influence of both extrinsic and intrinsic signals that govern their fate (Yen \& Wright 2006).
Additive examples of tissues with high turnover include the skin and cornea. The thyroid instead falls within the organs such as heart, muscle, brain and liver (Coclet et al. 1989, Dumont et al. 1992) that exhibit a low cell turnover, where the stem cell compartment or niche is not well limited and remains hidden. This has led some authors to suggest that in these organs the putative role of stem cells is of lower importance to organ homeostasis and not necessary as in renewing shedding epithelia (Prof. JE Dumont and Prof. ED Williams International Thyroid Meeting, Paris, 11-16 September 2010). In addition, the role of thyroid stem cells in tissue homeostasis, wounding response or reparation after the thyroiditis process remains to be proven.

Some important speculations were also addressed by the analysis of thyroid growth models. It has to be underlined that in spite of the low cell turnover that guarantees its size during a lifetime, the thyroid retains the capacity to grow by cell hypertrophy and proliferation in response to a stimulus that is controlled by the physiological negative feedback mechanism of TSH (Larsen 1982). The frequent and heterogeneous presentation in growth and function of benign and malignant nodular pathology cannot be simply explained by genetic background, environmental factors (Peter et al. 1982), iodine deficiency (Studer et al. 1974), mutagenic events, altered 
hormonal events and/or receptor/ligand interaction (reviewed in Derwahl \& Studer (2002) and Krohn et al. (2005)).

In this complex heterogeneity in growth and function, the role of the expanded committed progenitor cell compartments of different clonal origins must be prominent rather than of stem cells. These are estimated to increase up to $1-2 \%$ of nodular goitre cells (Gibelli et al. 2009); however, their specific behaviour and contribution in goitrogenesis in the opposing programs of proliferation and differentiation remain to be further elucidated.

Experimental data have also been reported that diminish the putative role of thyroid stem cells in the regenerative process (Prof. Dumont, International Thyroid Meeting 2010, Paris) and growth. For instance, mice and human differentiated thyrocytes divide (Ramelli et al. 1982, Coclet et al. 1989) and can generate new follicles (Peter et al. 1982), without the need for thyroid stem cells. Transplantation experiments in nude mice have also suggested the presence within nodular goitre tissues of autonomously growing thyroid-derived cells (Peter et al. 1985). New follicles can derive from single cells of a thyroid epithelium of polyclonal origin. It is also remarkable that mice-rat thyrocytes can divide up to five times under physiological stimulus, then stop dividing (Wynford-Thomas et al. 1982). Regrowth after exeresis of the thyroid gland in congenital hyperthyroidism (Holzapfel et al. 1997) implies the prominent role of differentiated cells with constitutive activation of the TSH-R. In the light of the aforegoing, I must address that if stem cells are apparently not strictly necessary for tissue renewal or physiology, this is not a valid argument to state that they cannot exist.

\section{Thyroid CSCs}

It has been pointed out that cancer is characterised by mutations responsible for uncontrolled cell proliferation (Klonisch et al. 2009). Resident stem cells are nowadays considered the main candidates for transformation and tumourigenesis, as highlighted above. It is generally recognised that CSCs within tumours (Bomken et al. 2010) represent a small population of cells with self-renewing ability and that are responsible for maintaining tumour bulk, the metastatic process and tumour resistance to conventional anticancer therapies (Bomken et al. 2010, Malaguarnera et al. 2010). This hypothesis was also presented for the origin of thyroid tumours (Lin 2011). It is still a matter of debate whether thyroid CSCs derive from de-differentiation of mature thyrocytes (Mitsutake et al. 2007, Thomas et al. 2008, Gibelli et al. 2009); alternatively, they could derive, according to the foetal stem cell carcinogenesis hypothesis, from normal stem or progenitor cells. Therefore, different levels of altered biological pathways would be responsible for different histological patterns with different degrees of aggressiveness. The transformation of thyroid stem cells would be at the origin of anaplastic thyroid carcinomas (ATCs), the transformation of thyroblasts would lead to PTC and that of prothyrocytes to FTC (Takano 2007).

In the paper by Mitsutake et al. (2007), the presence of SP cells was evaluated due to their ability to exclude the DNA binding dye Hoechst 33342 in five thyroid cancer cell lines: two anaplastic (ARO and FRO), two papillary (NPA and TPC1) and one follicular cancer cell line (WRO). SP cells were, therefore, sorted and cultured in vitro. After 10 days expansion, the cells were restained with Hoechst 33342 and reanalysed. The SP cells repopulated both SP and non-SP cells. The clonogenic ability of SP cells was significantly higher than that of non-SP cells. Microarray experiments revealed a differential gene expression profile between $\mathrm{SP}$ and non-SP cells. Quantitative real-time RT-PCR revealed that six genes were upregulated in SP cells: $A B C G 2, M Y C, J U N$, FZD5, HES1 and JAG1 (Tables 2-4). SP cells were tumourigenic when injected into nude mice. The non-SP population also contained tumourigenic cells.

Zito et al. (2008) demonstrated CD133-positive cells in ARO and KAT4 cell lines by means of flow cytometry, RT-PCR and immunocytochemistry (Tables 2-4). These lines were also positive for the marker oncofoetal fibronectin and negative for thyroid-specific differentiation markers. Sorted CD133-positive cells exhibited higher proliferation, self-renewal, colony-forming ability than ARO/CD133negative cells. The expression of the stem cell marker OCT4 detected by RT-PCR was markedly higher in ARO/CD133-positive than in ARO/CD133-negative cells.

Friedman et al. (2009) showed that CD133-positive ATC cells (from ARO and FRO cell lines), but not CD133 negative ATC cells, induced tumours in vivo when injected into immunodeficient NOD/SCID mice. The CD133-positive cell pool could be separated by flow cytometry into two distinct populations: cells highly expressing CD133 and cells with low CD133 expression. The rapidly proliferating cells, highly positive for CD133, were most efficient in long-term tumourigenesis. This subset also expressed high levels of the SCA OCT4 and the TSH-R. When ATC cells were treated with TSH, there was a threefold increase in the number of $\mathrm{CD}_{133^{+}}$cells and a dose-dependent upregulation of OCT4 and TSH-R in these cells. However, Ringel (2008) emphasised that caution is warranted when considering the existence of CSC populations in ATCs, because derived lines have been found to be contaminated and not of thyroid origin after genetic evaluation (DNA fingerprint) to ascertain their identity and stability (Tables 3 and 4).

Recently, cancer thyrospheres with stem/progenitor-like cell properties were isolated from three human PTCs (Malaguarnera et al. 2010) according to previously established protocols (Lan et al. 2007; Tables 2-4). The generated lines were positive for several putative stem cell markers: OCT4, ABCG2, SOX2 (or SRY box protein 2, sex determining region $\mathrm{Y}$ box protein 2), CD133, CD44 and NANOG, expressed at much higher levels than in normal thyrospheres; they showed low levels of TTF1, PAX8 and TSH-R, while being totally negative for other thyroid-specific differentiation 
markers and specific for other lineages (mesenchymal, neural and haematopoietic). The expression of differentiation markers gradually increased in normal sphere-derived differentiating cells; the highest expression was reached after 21 days of TSH treatment. In agreement with the poorly differentiated phenotype of the thyroid cancer specimens of origin, cancer thyrospheres did not differentiate when exposed to serum and TSH. It was shown that insulin receptor (IR) isoforms and IGF receptor (IGF-IR) play a role in the biology of follicular thyroid precursors, which may open the pathway to future differentiation therapies in thyroid cancer (Malaguarnera et al. 2010). Cancer thyrospheres expressed a higher IR:IGF-IR ratio in comparison with thyrospheres from normal thyroid tissue obtained from patients who underwent surgical treatment for solitary benign adenoma.

Todaro et al. (2010) recently clearly showed that thyroid cancer derives from a small population of CSCs that account for $1 \cdot 2-3 \cdot 5 \%$ of the whole thyroid cancer population. In the isolation procedure, thyroid cells were resuspended in medium containing EGF and bFGF and plated on ultralow adhesion 96-well plates at a concentration of a single cell per well. CSCs possessed high aldehyde dehydrogenase activity $\left(\mathrm{ALDH}^{\text {high }}\right)$. An elevated percentage of cells expressing this marker were self-renewing with unlimited replication potential and clonogenic properties when cultured in serum-free medium. They grew as cancer thyrospheres; during their formation, single cells with ALDH ${ }^{\text {high }}$ replicate with symmetrical and asymmetrical cell division and produce other clonogenic cells together with a progeny with limited proliferation capacity. By means of immunocytochemistry and flow cytometry, the expression of differentiation/ stemness markers was analysed; distinct protein expression profiles were observed among the different cancer types (Table 3). TG and the transcription factor TTF1 were detected in all PTC and FTCs but were reduced or absent in anaplastic thyroid cancer (UTC). CD133 was not detected. Cancer thyrospheres, when injected in immunodeficient mice, generated tumour xenografts with constitutive activation of the cMET/AKT (Engelman et al. 2007, Moumen et al. 2007) pathway, known to be related to an aggressive phenotype. Based on the detection of ALDH1 activity, CSCs were also identified within the human UTC-8505C cell line (reviewed in Klonisch et al. (2009)).

In the recent study by Zheng et al. (2010), ATC cell lines that consisted of $0 \cdot 4-0 \cdot 8 \%$ SP cells expressed ABCG2 and multi-drug-resistant 1 (MDR1) transporter. Doxorubicin treatment eliminated the non-SP cells. OCT4-positive CSC exhibited a growth advantage.

Table 3 Putative stem/progenitor markers analysed in different histotypes of thyroid cancer or cancer cell lines

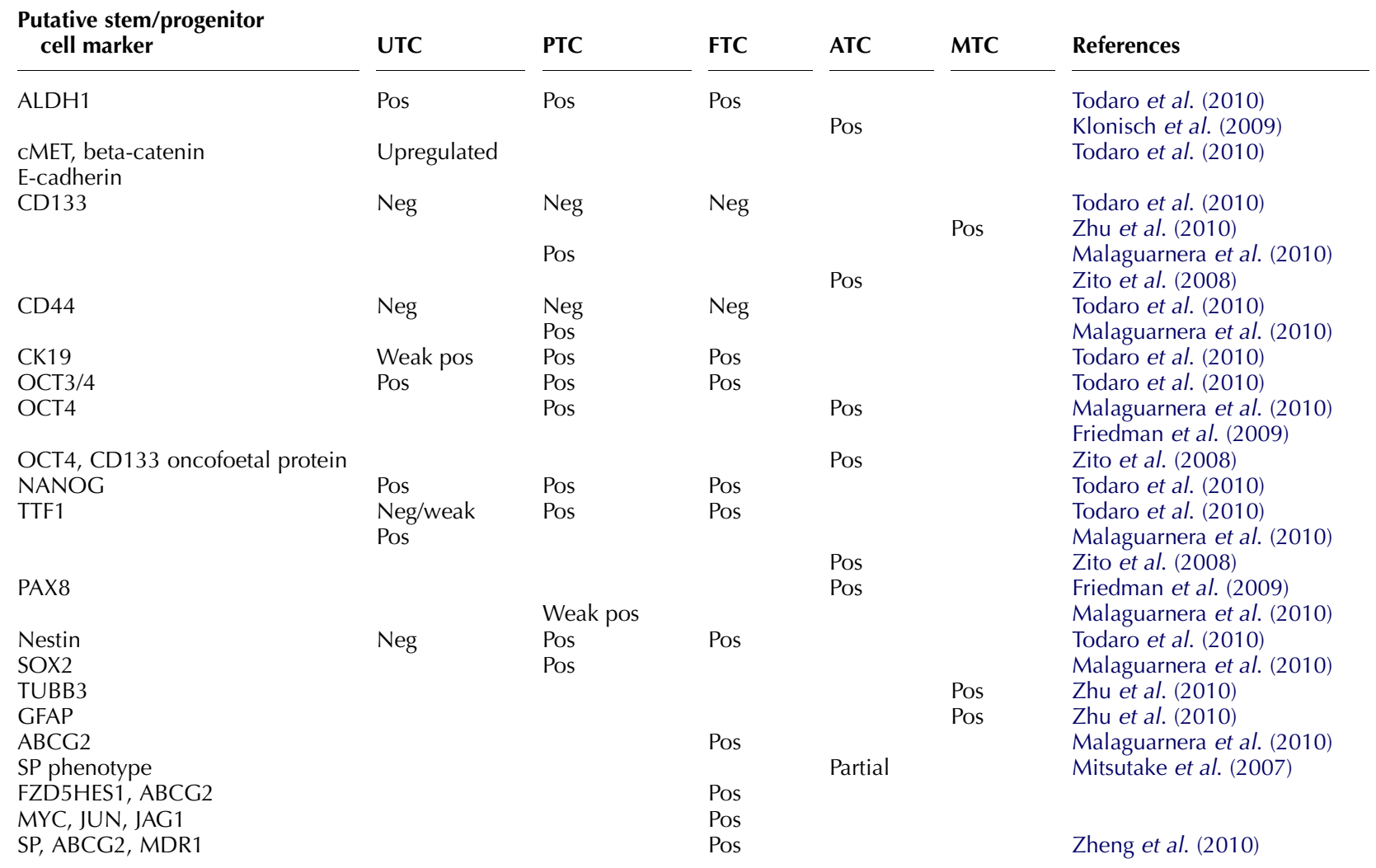

JAG1, jagged protein 1. 
Table 4 Thyroid differentiation markers in cancer stem/progenitor cells derived from different histotypes or thyroid cancer or cancer cell lines

\begin{tabular}{|c|c|c|c|c|c|}
\hline $\begin{array}{l}\text { Thyroid differentiation } \\
\text { marker }\end{array}$ & UTC & PTC & FTC & ATC & References \\
\hline \multirow[t]{4}{*}{ TG } & Neg/weak & Pos & Pos & & \\
\hline & Pos & & & & Todaro et al. (2010) \\
\hline & & & & Neg & Friedman et al. (2009) \\
\hline & Neg & & & & Zito et al. (2008) \\
\hline TPO, NIS & & & & Neg & $\begin{array}{l}\text { Zito et al. (2008) } \\
\text { Friedman et al. (2009) }\end{array}$ \\
\hline TPO, TSH-R & & Weak pos & & & Malaguarnera et al. (2010) \\
\hline TSH-R & & & & Pos & Friedman et al. (2009) \\
\hline NIS & & & & Neg & Friedman et al. (2009) \\
\hline
\end{tabular}

Zhu et al. (2010) recently proved the existence of CSCs also in medullary thyroid carcinoma (MTC) cell lines. It is well known that dominant-activating mutations of the rearranged during transfection (RET) tyrosine kinase receptor protooncogene play a fundamental role in the development of MTC (Santarpia et al. 2009). The authors pointed out that, although a universal marker for CSC has not yet been identified, these cells were positive for CD133 and demonstrated for the first time a crucial role for RET protooncogene, bFGF and EGF in CSC self-renewal. These cell lines also expressed additional neuronal line-specific markers consistent with their neural progenitor cell origin: $\beta$-tubulin isotype III (TUBB3) and glial fibrillar acidic protein (GFAP). They speculate, therefore, that the three factors contribute to MTC progression because they favour CSC renewal. Novel experimental evidence suggests that new avenues for MTC treatment should aim to inhibit tyrosine kinase receptors as well as target bFGF and EGF receptors (Ezzat et al. 2005, Santarpia et al. 2009).

\section{Discussing the putative role of thyroid CSCs}

In principle, the re-expression of some SSC and ESC markers (i.e. OCT4) in thyroid tumours may support their generation from stem cells (Tables 2-3). An ESC-like gene expression is found in poorly differentiated aggressive human tumours, suggesting that, putatively, these genes contribute to their stem cell phenotype (Ben Porath et al. 2008).

Nevertheless, arguments have been raised against the hypothesis that SSCs are at the origin of thyroid tumours. As reported by Prof. JE Dumont and Prof. ED Williams at the International Thyroid Meeting in Paris, 11-16 September 2010, papillae can simply generate from follicles (Peter et al. 1985) and highly malignant tumours may arise from preexisting low-grade tumours (Williams 1995). Of note, transgenic models of thyroid tumours utilise oncogenes under the control of the TG promoter (Knostman et al. 2007), which is active only in differentiated cells. In case of tumours from stem cell tissues like testicular germ cells tumours, the stem cell origin of cancer is obvious. In addition, they express the canonical ESC transcription factors (NANOG, OCT3/4 and SOX2; Kristensen et al. 2008).
While the concept of the CSC origin in tissues in which the life of non-stem cells is short, such as blood, colon, uterus, prostate, skin and mucosa (Wicha et al. 2006) is plausible, this is less evident for tissues with long living cells that can multiply several times (i.e. liver and thyroid). In particular, thyroid tumours (benign or malignant, FTC, PTC) are composed of well-differentiated slow-growing cells (Prof. Dumont, Prof. Williams communication at the International Thyroid Meeting in Paris, 11-16 September 2010). Another important argument that was raised is the observed increasing malignancy in thyroid related to increased number of undifferentiated cells with the aging process.

On a general ground, arguments have also been recently raised related to the properties that different authors have considered to define CSCs and their derivatives (Maenhaut et al. 2010). The unique population of CSCs should express a distinct repertoire of surface markers to allow their isolation and purification. Nevertheless, markers proposed by different authors are different for the different types of cancers and different from those of SSCs. As shown in Table 3, this clearly applies to thyroid CSCs that have been identified by different procedures, examined and found positive for different markers. The second property relates to the selectively endowed tumourigenicity for CSCs that implies the existence of two populations of cells: the selfrenewing and immortal CSSs and the derived population with limited lifespan, therefore innocuous. According to some authors, CSCs correspond to SP cells. This concept is directly transposed from the SSC concept replacing tissue regeneration by the potential to generate tumours (Maenhaut et al. 2010).

Certainly, if generally accepted for SSCs, some properties cannot be simply ascribed to CSCs as well. These include the existence of a niche, the asymmetric cell division, and the fact that derived cells are originated by a deterministic, irreversible and qualitative process, without intermediate quantitatively modified products. Rather, CSCs could be more appropriately defined as tumour-propagating cells (TPC-CSC) with properties maintained by (epi)genetic mechanisms leading to heterogeneity and partially reversible. CSCs would have originated instead by a quantitative stochastic process (Maenhaut et al. 2010). 
As proposed by Dalerba et al. (2007) (reviewed in Floor et al. (2011)), the minimal definition of TPC-CSC is that of cancer cells with infinite lifespan able to generate all types of differentiated cells found in a cancer. Independent of the latest concept, the existence of other populations of cancer cells with special properties has been hypothesised. These include cells in epithelial-mesenchymal transition (EMT; Cannito et al. 2010). This concept derives from the observation that tumour progresses locally by cell migration; however, some cells detach and undergo EMT, migrating separately with the appearance of mesenchymal stem cells. Reversible EMT can be induced in vitro by extracellular matrix or factors (Coclet et al. 1991). In specialised cells like dog and rat thyrocytes, this progress is promoted by hepatocyte growth factor, EGF or even by culturing cells (Coclet et al. 1991). Classical growth factors such as TGF $\beta$ but also EGF contribute to the generation of both CSC and EMT phenotypes. In particular, TGF $\beta$ is overexpressed at the invasive front of PTC (Riesco-Eizaguirre et al. 2009). Of note, EMT cells, if they act as vectors of metastasis, should be TPC-CSC to generate all the types of metastasis. On the contrary, TPC-CSC to metastasise should undergo EMT and subsequently mesenchymalepithelial transition (MET).

The term TIC (vide supra) has also been proposed, which does not imply any conclusion regarding the origin. However, this concept remains debated (Shipitsin et al. 2007). It is quite important to observe the behaviours of cancer cell lines that are supposed to derive from a selection of CSCs (van Staveren et al. 2009). During their generation, cancer cells initially multiply and then develop foci from which they start growing (Masters 2000). It was observed that, if they derive from CSCs, they would proliferate as ESCs and not as adult tissue stem cells. Remarkably, when cancer cell lines are injected in vivo, they only reproduce some of the features of in vivo tumours. This has led to the hypothesis that all the cells in a cell line culture instead act as TIC-CSC (van Staveren et al. 2009).

\section{Final summary and conclusions}

The potential of stem cells has mainly been envisaged in the management of debilitating human disorders on account of their theoretical ability to transdifferentiate into clinically significant amounts of functional pancreatic $\beta$ cells, hepatocytes, cardiomyocytes and neurons. Therefore, new perspectives have opened up regarding the treatment of neurological conditions such as Parkinson's disease, heart diseases such as myocardial infarction, and insulin-dependent diabetes mellitus (type 1 diabetes).

The thyroid represents a critical hormone-producing organ whose function is compromised in several conditions including goitre, adenomas, hypothyroidism and autoimmune diseases (Braverman \& Utiger 1991). Research has to find solutions and exploit novel strategies to improve their management.
In the future, a new avenue of 'tailored' therapies for the benefit and personalised care of thyroid patients could theoretically be opened by the use of novel sources of adult stem/progenitor cell populations, although (vide supra) criticism has been raised against the putative role of thyroid stem cells in the regeneration process. In spite of all the concerns, the issue of generating thyrocytes from stem cells must be definitively pursued to answer relevant questions in basic science that are prerequisites to any translational application. Appropriateness of methodologies so far employed for the identification of stem cells in the thyroid has been debated (Prof. JE Dumont, International Thyroid Meeting, Paris, 11-16 September 2010). I must emphasise that so far published studies only provide evidence on the existence of thyroid stem cells and of thyroid progenitors (vide supra). However, there is no consensus regarding the protocols employed for their identification and differentiation by, from time to time, isolating SP, detection of 'stem cell markers' in histological slides or generation of thyrospheres. In addition, often there is not a clear step-by-step presentation of the protocols in the papers mentioned above. Notably, multipotent stem cells recognised by 'unique' markers have not been isolated from the normal human thyroid and its benign pathology. Thus, many issues remain open.

Another priority question that remains to be answered in the mentioned studies is to prove whether fully differentiated and functional thyrocytes are obtainable in vivo after the in vitro expansion of thyroid stem/progenitor cells. These cells should express all the different thyroid differentiation markers and be capable of iodine incorporation. Therefore, before envisaging their use in replacement strategies, it would be mandatory to first demonstrate that these cells, when transplanted into a hypothyroid animal model, can actively participate in the regeneration of mature functional thyroid follicles (Fierabracci et al. 2008). Another essential condition would be that, before injection, the proliferative capacity of the precursor population of adult stem cells must be appropriately monitored. The ideal stem/progenitor cell population must be capable of in vitro expansion to clinically useful quantities of mature thyroid replacement cells.

As outlined above (vide infra), with the basic science data available so far, it is not possible to extrapolate any conclusion on the utility of the identified sources of cells in the treatment of thyroid disorders. In light of the extensive debate that has been recently raised on CSCs, the same considerations can also apply to this population. The new concepts of TPC-CSC, TIC and EMT clearly indicate that more research has to be extensively performed before elucidating the question of the origin of thyroid tumours and being able to unravel future translation strategies for treatment.

\section{Declaration of interest}

The author declares that there is no conflict of interest that could be perceived as prejudicing the impartiality of the research reported. 


\section{Funding}

The research work was supported by the Italian Ministry of Health.

\section{References}

Alessandri G, Pagano S, Bez A, Benetti A, Pozzi S, Iannolo G, Baronio M, Invernici G, Caruso A, Muneretto C et al. 2004 Isolation and culture of human muscle-derived stem cells able to differentiate into myogenic and neurogenic cell lineages. Lancet 364 1872-1883. (doi:10.1016/S01406736(04)17443-6)

Arufe MC, Lu M, Kubo A, Keller G, Davies TF \& Lin RY 2006 Directed differentiation of mouse embryonic stem cells into thyroid follicular cells Endocrinology 147 3007-3015. (doi:10.1210/en.2005-1239)

Arufe MC, Lu M \& Lin RY 2009 Differentiation of murine embryonic stem cells to thyrocytes requires insulin and insulin-like growth factor-1. Biochemical and Biophysical Research Communications 381 264-270. (doi:10.1016/j.bbrc.2009.02.035)

Baschieri L, Castagna M, Fierabracci A, Antonelli A, Del Guerra P \& Squartini F 1989 Distribution of calcitonin- and somatostatin-containing cells in thyroid lymphoma and in Hashimoto's thyroiditis. Applied Pathology 7 99-104.

Beck-Peccoz P, Persani L \& LaFranchi S 2004 Safety of medications and hormones used in the treatment of pediatric thyroid disorders. Pediatric Endocrinology Reviews 2 (Suppl 1) 124-133.

Ben Porath I, Thomson MW, Carey VJ, Ge R, Bell GW, Regev A \& Weinberg RA 2008 An embryonic stem cell-like gene expression signature in poorly differentiated aggressive human tumors. Nature Genetics 40 499-507. (doi:10.1038/ng.127)

Bertoncello I \& McQualter J 2011 Isolation and clonal assay of adult lung epithelial stem/progenitor cells. In Current Protocols in Stem Cell Biology, Chapter 2: Unit 2G.1.

Bomken S, Fišer K, Heidenreich O \& Vormoor J 2010 Understanding the cancer stem cell. British Journal of Cancer 103 439-445. (doi:10.1038/sj.bjc. 6605821)

Braverman LE \& Utiger RD 1991 The thyroid. A fundamental and clinical text. In Werner and Ingbar's, 7th edn. Philadelphia: Lippincott-Raven.

Burger PE, Gupta R, Xiong X, Ontiveros CS, Salm SN, Moscatelli D \& Wilson EL 2009 High aldehyde dehydrogenase activity: a novel functional marker of murine prostate stem/progenitor cells. Stem Cells 27 2220-2228. (doi:10.1002/stem.135)

Burstein DE, Nagi C, Wang BY \& Unger P 2004 Immunohistochemical detection of p53 homolog p63 in solid cell nests, papillary thyroid carcinoma, and Hashimoto's thyroiditis: a stem cell hypothesis of papillary carcinoma oncogenesis. Human Pathology 35 465-473. (doi:10.1016/j. humpath.2003.10.027)

Cameselle-Teijeiro J, Febles-Pérez C \& Sobrinho-Simôes M 1995 Papillary and mucoepidermoid carcinoma of the thyroid with anaplastic transformation: a case report with histologic and immunohistochemical findings that support a provocative histogenetic hypothesis. Pathology Research and Practice 191 1214-1221. (doi:10.1016/S0344-0338(11)81129-5)

Cannito S, Novo E, di Bonzo LV, Busletta C, Colombatto S \& Parola M 2010 Epithelial-mesenchymal transition: from molecular mechanisms, redox regulation to implications in human health and disease. Antioxidants $\mathcal{E}$ Redox Signaling 12 1383-1430. (doi:10.1089/ars.2009.2737)

Chambers I, Colby D, Robertson M, Nichols J, Lee S, Tweedie S \& Smith A 2003 Functional expression cloning of NANOG, a pluripotency sustaining factor in embryonic stem cells. Cell 113 643-655. (doi:10.1016/S00928674(03)00392-1)

Coclet J, Foureau F, Ketelbant P, Galand P \& Dumont JE 1989 Cell population kinetics in dog and human adult thyroid. Clinical Endocrinology 31 655-665. (doi:10.1111/j.1365-2265.1989.tb01290.x)

Coclet J, Lamy F, Rickaert F, Dumont JE \& Roger PP 1991 Intermediate filaments in normal thyrocytes: modulation of vimentin expression in primary cultures. Molecular and Cellular Endocrinology 76 135-148. (doi:10.1016/0303-7207(91)90268-W)
Cohen A, Rovelli A, Merlo DF, van Lint MT, Lanino E, Bresters D, Ceppi M, Bocchini V, Tichelli A \& Socié G 2007 Risk for secondary thyroid carcinoma after hematopoietic stem-cell transplantation: an EBMT late effects working party study. Journal of Clinical Oncology 25 2449-2454. (doi:10.1200/JCO.2006.08.9276)

Dalerba P, Cho RW \& Clarke MF 2007 Cancer stem cells: models and concepts. Annual Review of Medicine 58 267-284. (doi:10.1146/annurev. med.58.062105.204854)

Daley GQ 2010 Stem cells: roadmap to the clinic. Journal of Clinical Investigation 120 8-10. (doi:10.1172/JCI41801)

Davies TF, Latif R, Minsky NC \& Ma R 2011 The emerging cell biology of thyroid stem cells. Journal of Clinical Endocrinology and Metabolism 96 2692-2702. (doi:10.1210/jc.2011-1047)

De Felice M \& Di Lauro R 2004 Thyroid development and its disorders: genetics and molecular mechanisms. Endocrine Reviews 25 722-746. (doi:10.1210/er.2003-0028)

Derwahl M \& Studer H 2002 Hyperplasia versus adenoma in endocrine tissues: are they different? Trends in Endocrinology and Metabolism 13 23-28. (doi:10.1016/S1043-2760(01)00519-7)

Di Lauro R \& De Felice M 2001 Thyroid gland: anatomy and development in endocrinology. In Endocrinology, 4th edn, pp 1268-1277. Eds LJ DeGroot \& JL Jameson. Philadelphia, PA: WB Saunders.

Doniach I 1974 Handbook of Physiology, vol 3, 3rd edn, pp 359-375. Eds MA Greer \& DH Solomon. American Physiological Society: Washington 7.

Dumont JE, Lamy F, Roger P \& Maenhaut C 1992 Physiological and pathological regulation of thyroid cell proliferation and differentiation by thyrotropin and other factors. Physiological Reviews 72 667-697.

Edling CE \& Hallberg B 2007 C-kit a hematopoietic essential receptor tyrosine kinase. International Journal of Biochemistry \& Cell Biology 39 1995-1998. (doi:10.1016/j.biocel.2006.12.005)

Engelman JA, Zejnullahu K, Mitsudomi T, Song Y, Hyland C, Park JO, Lindeman N, Gale CM, Zhao X, Christensen J et al. 2007 MET amplification leads to gefitinib resistance in lung cancer by activating ERBB3 signaling. Science 316 1039-1043. (doi:10.1126/science.1141478)

Ezzat S, Huang P, Dackiw A \& Asa SL 2005 Dual inhibition of RET and FGFR 4 restraind medullary thyroid cancer cell growth. Clinical Cancer Research 11 1336-1341.

Fierabracci A, Castagna M \& Baschieri L 1993 Calcitonin and somatostatin containing $\mathrm{C}$ cells in rat and human thyroid. Immunohistochemical study by a double-staining method. Pathologica 85 467-474.

Fierabracci A, Caione P, Di Giovine M, Zagaglia D \& Bottazzo GF 2007 Identification and characterisation of adult stem/progenitor cells in the human bladder (bladder spheroids): perspectives of application in pediatric surgery. Pediatric Surgery International 23 837-839. (doi:10.1007/s00383007-1906-x)

Fierabracci A, Puglisi MA, Giuliani L, Mattarocci S \& Gallinella-Muzi M 2008 Identification of an adult stem/progenitor cell population in the human thyroid. Journal of Endocrinology 198 471-487. (doi:10.1677/JOE07-0552)

van der Flier LG \& Clevers H 2009 Stem cells, self-renewal, and differentiation in the intestinal epithelium. Annual Reviews of Physiology 71 241-260. (doi:10.1146/annurev.physiol.010908.163145)

Floor S, van Staveren WCG, Larsimont D, Dumont JE \& Maenhaut C 2011 Cancer cells in epithelial-to-mesenchymal transition and tumor-propagating-cancer stem cells: distinct, overlapping or same populations. Oncogene (doi: 10.1038/onc.2011.184).

Friedman S, Lu M, Schultz A, Thomas D \& Lin R-Y 2009 CD133 ${ }^{+}$ anaplastic thyroid cancer cells initiate tumors in immunodeficient mice and are regulated by thyrotropin. PLoS ONE 4 e5395. (doi:10.1371/journal. pone.0005395)

Gibelli B, El-Fattah AMA, Giugliano G, Proh M \& Grosso E 2009 Thyroid stem cells - danger or resource? Acta Otorhinolaryngologica Italica 29 290-295.

Gibson WG, Peng TC \& Croker BP 1982 Age-associated C-cell hyperplasia in the human thyroid. American Journal of Pathology 106 388-393.

Goodell MA, Brose K, Paradis G, Conner AS \& Mulligan RC 1996 Isolation and functional properties of murine hematopoietic stem cells that are replicating in vivo. Journal of Experimental Medicine 183 1797-1806. (doi:10.1084/jem.183.4.1797) 
Gritti A, Parati EA, Cova L, Frolichsthal P, Galli R, Wanke E, Faravelli L, Morassutti DJ, Roisen F, Nickel DD et al. 1996 Multipotential stem cells from the adult mouse brain proliferate and self-renew in response to basic fibroblast growth factor. Journal of Neuroscience 16 1091-1100.

Guazzi S, Price M, De Felice M, Damante G, Mattei MG \& Di Lauro R 1990 Thyroid nuclear factor 1 (TTF-1) contains a homeodomain and display a novel DNA binding specificity. EMBO Journal 9 3631-3639.

Gussoni E, Soneoka Y, Strickland CD, Buzney EA, Khan MK, Flint AF, Kunkel LM \& Mulligan RC 1999 Dystrophin expression in the mdx mouse restored by stem cell transplantation. Nature 401 390-394.

Hicok KC \& Hedrick MH 2011 Automated isolation and processing of adipose-derived stem and regenerative cells. Methods in Molecular Biology 702 87-105.

Holzapfel H-P, Wonerow P, von Petrykowski W, Henschen M, Scherbaum WA \& Paschke R 1997 Sporadic congenital hyperthyroidism due to a spontaneous germline mutation in the thyrotropin receptor gene. Journal of Clinical Endocrinology and Metabolism 82 3879-3884. (doi:10.1210/jc.82.11.3879)

Hoshi N, Kusakabe T, Taylor BJ \& Kimura S 2007 Side population cells in the mouse thyroid exhibit stem/progenitor cell-like characteristics. Endocrinology 148 4251-4258. (doi:10.1210/en.2006-0490)

Houbracken I \& Bouwens L 2010 The quest for tissue stem cells in the pancreas and other organs and their application in beta-cell replacement. Review of Diabetic Studies 7 112-123. (doi:10.1900/RDS.2010.7.112)

Hussain SZ, Strom SC, Kirby MR, Burns S, Langemeijer S, Ueda T, Hsieh M \& Tisdale JF 2005 Side population cells derived from adult liver generate hepatocyte-like cells in vitro. Digestive Diseases and Sciences 50 1755-1763. (doi:10.1007/s10620-005-2933-x)

Jiang N, Hu Y, Liu X, Wu Y, Zhang H, Chen G, Liang J, Lu X \& Liu S 2010 Differentiation of E14 mouse embryonic stem cells into thyrocytes in vitro. Thyroid 20 77-84. (doi:10.1089/thy.2008.0291)

Kanazawa T, Konno A, Hashimoto Y \& Kon Y 2009 Expression of hepatocyte nuclear factor 4 alpha in developing mice. Anatomia, Histologia, Embryologia 38 34-41. (doi:10.1111/j.1439-0264.2008.00889.x)

Klintschar M, Schwaiger P, Mannweiler S, Regauer S \& Kleiber M 2001 Evidence of fetal microchimerism in Hashimoto's thyroiditis. Journal of Clinical Endocrinology and Metabolism 86 2494-2498. (doi:10.1210/jc.86.6. 2494)

Klonisch T, Hoang-Vu C \& Hombach-Klonisch S 2009 Thyroid stem cells and cancer. Thyroid 19 1303-1315. (doi:10.1089/thy.2009.1604)

Knostman KAB, Venkateswaran A, Zimmerman B, Capen CC \& Jhiang SM 2007 Creation and characterization of a doxycycline-inducible mouse model of thyroid-targeted RET/PTC1 oncogene and luciferase reporter gene coexpression. Thyroid 17 1181-1188. (doi:10.1089/thy.2007.0224)

Koopmans M, Kremer Hovinga IC, Baelde HJ, Harvey MS, de Heer E, Bruijn JA \& Bajema IM 2008 Chimerism occurs in thyroid, lung, skin and lymph nodes of women with sons. Journal of Reproductive Immunology 78 68-75. (doi:10. 1016/j.jri.2008.01.002)

Kristensen DM, Sonne SB, Ottesen AM, Perrett RM, Nielsen JE, Almstrup K, Shakkebaek NE, Leffers H \& Meyts ER 2008 Origin of pluripotent germ cell tumours: the role of microenvironment during embryonic development. Molecular and Cellular Endocrinology 288 111-118. (doi:10.1016/j.mce.2008. 02.018)

Krohn K, Fűhrer D, Bayer Y, Brauer V, Neumann S \& Paschke R 2005 Molecular pathogenesis of euthyroid and toxic multinodular goiter. Endocrine Reviews 26 504-524. (doi:10.1210/er.2004-0005)

Lan L, Cui D, Nowka K \& Derwahl M 2007 Stem cells derived from goiters in adults form spheres in response to intense growth stimulation and require thyrotropin for differentiation into thyrocytes. Journal of Clinical Endocrinology and Metabolism 92 3581-3688.

Larsen PR 1982 Thyroid-pituitary interaction: feedback regulation of thyrotropin secretion by thyroid hormones. New England Journal of Medicine 306 23-32. (doi:10.1056/NEJM198201073060107)

Li L \& Clevers H 2010 Coexistence of quiescent and active adult stem cells in mammals. Science 327 542-545. (doi:10.1126/science.1180794)

Liegeois A, Escourrou J, Ouvré E \& Charreire J 1977 Microchimerism: a stable state of low-ratio proliferation of allogeneic bone marrow. Transplantation Proceedings 9 273-276.
Lin RY 2007 New insights into thyroid stem cells. Thyroid 17 1-5. (doi:10. 1089/thy.2007.9998)

Lin RY 2011 Thyroid cancer stem cells. Nature Reviews. Endocrinology 7 609-616. (doi:10.1038/nrendo.2011.127)

Lin RY \& Davies TF 2010 Differentiating thyroid cells. Thyroid 20 1-2. (doi:10.1089/thy.2009.1613)

Lin RY, Kubo A, Keller GM \& Davies TF 2003 Committing embryonic stem cells to differentiate into thyrocyte-like cells in vitro. Endocrinology 144 2644-2649. (doi:10.1210/en.2002-0122)

Ma R, Latif R \& Davies TF 2009 Thyrotropin-independent induction of thyroid endoderm from embryonic stem cells by activin A. Endocrinology 150 1970-1975. (doi:10.1210/en.2008-1374)

Maenhaut C, Dumont JE, Roger PP \& van Staveren WCG 2010 Cancer stem cells: a reality, a myth, a fuzzy concept or a misnomer? An analysis Carcinogenesis 31 149-158. (doi:10.1093/carcin/bgp259)

Maiorana A, Fierabracci A \& Cianfarani S 2009 Isolation and characterisation of omental adipose progenitor cells in children: a potential tool to unravel the pathogenesis of metabolic syndrome. Hormone Research 72 348-358. (doi:10.1159/000249163)

Malaguarnera R, Frasca F, Garozzo A, Gianì F, Pandini G, Vella V, Vigneri R \& Belfiore A 2010 Insulin receptor isoforms and insulin-like growth factor receptor in human follicular cell precursors from papillary thyroid cancer and normal thyroid. Journal of Clinical Endocrinology and Metabolism 96 766-774. (doi:10.1210/jc.2010-1255)

Masters JR 2000 Human cancer cell lines: fact and fantasy. Nature Reviews. Molecular Cell Biology 1 233-236. (doi:10.1038/35043102)

Messina E, De Angelis L, Frati G, Morrone S, Chimenti S, Fiordaliso F, Salio M, Battaglia M, Latronico MV, Coletta M et al. 2004 Isolation and expansion of adult cardiac stem cells from human and murine heart. Circulation Research 95 911-921. (doi:10.1161/01.RES.0000147315.71699.51)

Mitsutake N, Iwao A, Nagai K, Namba H, Ohtsuru A, Saenko V \& Yamashita S 2007 Characterisation of side population in thyroid cancer cell lines: cancer stem-like cells are enriched partly but not exclusively. Endocrinology 148 1797-1803. (doi:10.1210/en.2006-1553)

Morrison SJ \& Spradling AC 2008 Stem cells and niches: mechanisms that promote stem cell maintenance throughout life. Cell 132 598-611. (doi:10.1016/j.cell.2008.01.038)

Moumen A, Ieraci A, Patane S, Solé C, Comella JX, Dono R \& Maina F 2007 MET signals hepatocyte survival by preventing FAS-triggered FLIP degradation in a PI3k-AKT-dependent manner. Hepatology 45 1210-1217. (doi:10.1002/hep.21604)

Mulcahi RT, Rose DP, Miteken JM \& Clifton KM 1980 Hormonal effects on the quantitative transplantation of monodispersed rat thyroid cells. Endocrinology 106 1769-1775. (doi:10.1210/endo-106-6-1769)

Nunes MC, Roy NS, Keyoung HM, Goodman RR, McKhann G II, Jiang L, Kang J, Nedergaard M \& Goldman SA 2003 Identification and isolation of multipotential neural progenitor cells from the subcortical white matter of the adult human brain. Nature Medicine 9 439-447. (doi:10.1038/nm837)

Pasca di Magliano M, Di Lauro R \& Zannini M 2000 PAX8 has a key role in thyroid cell differentiation. PNAS 97 13144-13149. (doi:10.1073/pnas. 240336397)

Peter HJ, Studer H, Forster R \& Gerber H 1982 The pathogenesis of 'hot' and 'cold' follicles in multinodular goiters. Journal of Clinical Endocrinology and Metabolism 55 941-946. (doi:10.1210/jcem-55-5-941)

Peter HJ, Gerber H, Studer H \& Smeds S 1985 Pathogenesis of heterogeneity in human multinodular goiters. A study on growth and function of thyroid tissue transplanted onto nude mice. Journal of Clinical Investigation 76 1992-2002. (doi:10.1172/JCI112199)

Puglisi MA, Giuliani L \& Fierabracci A 2008 Identification and characterisation of a novel expandable adult stem/progenitor cell population in the human exocrine pancreas. Journal of Endocrinological Investigation 31 563-572.

Ramelli F, Studer H \& Bruggisser D 1982 Pathogenesis of thyroid nodules in multinodular goiter. American Journal of Pathology 109 215-223.

Reis-Filho JS, Preto A, Soares P, Ricardo S, Cameselle-Teijeiro J \& Sobrinho-Simoes M 2003 P63 expression in solid cell nests of the thyroid: further evidence for a stem cell origin. Modern Pathology 16 43-48. (doi:10.1097/01.MP.0000047306.72278.39) 
Riesco-Eizaguirre G, Rodriguez I, De la Vieja A, Costamagna E, Carrasco N, Nistal M \& Santisteban P 2009 The BRAFV600E oncogene induces transforming growth factor beta secretion leading to sodium iodide symporter repression and increased malignancy in thyroid cancer. Cancer Research 69 8317-8325. (doi:10.1158/0008-5472.CAN-09-1248)

van de Rijn M, Heimfeld S, Spangrude GJ \& Weissman IL 1989 Mouse hematopoietic stem-cell antigen SCA1 is a member of the LY6 antigen family. PNAS 86 4634-4638. (doi:10.1073/pnas.86.12.4634)

Ringel MD 2008 'Thyroid cancer' cell line misidentification: a time for proactive change. Journal of Clinical Endocrinology and Metabolism 93 4226-4227. (doi:10.1210/jc.2008-2008)

Rios Moreno MJR, Galera-Ruiz H, De Miguel M, López MI, Illanes M \& Galera-Davidson H 2010 Immunohistochemical study of solid cell nest of the thyroid gland. Endocrine Pathology 22 35-39. (doi:10.1007/s12022-0109145-4)

Sanders JE, Hoffmeister PA, Woolfrey AE, Carpenter PA, Storer BE, Storb RF \& Appelbaum FR 2009 Thyroid function following hematopoietic cell transplantation in children: 30 years' experience. Blood 113 306-308. (doi:10.1182/blood-2008-08-173005)

Santarpia L, Ye L \& Gagel RF 2009 Beyond RET: potential therapeutic approaches for advanced and metastatic medullary thyroid carcinoma. Journal of Internal Medicine 266 99-113. (doi:10.1111/j.1365-2796.2009. 02112.x)

Sherwood RI, Christensen JL, Weissman IL \& Wager AJ 2004 Determinants of skeletal muscle contribution from circulating cells, bone marrow cells, and hematopoietic stem cells. Stem Cells 22 1292-1304. (doi:10.1634/ stemcells.2004-0090)

Shipitsin M, Campbell LL, Argani P, Weremowicz N, Bluoshtain-Qimron N, Yao J, Nikolskaya T, Beroukhim R, Hu M, Halushka MK et al. 2007 Molecular definition of breast tumor heterogeneity. Cancer Cell 11 259-273. (doi:10.1016/j.ccr.2007.01.013)

Shivtiel S, Kollet O, Lapid K, Schajnovitz A, Goichberg P, Kalinkovich A, Shezen E, Tesio M, Netzer N, Petit I et al. 2008 CD45 regulates retention, motility, and numbers of hematopoietic progenitors, and affects osteoclast remodeling of metaphyseal trabecules. Journal of Experimental Medicine 205 2381-2395. (doi:10.1084/jem.20080072)

Srivatsa B, Srivatsa S, Johnson KL, Samura O, Lee SL \& Bianchi DW 2001 Microchimerism of presumed fetal origin in thyroid specimens from women: a case-control study. Lancet 358 2034-2038. (doi:10.1016/S01406736(01)07099-4)

van Staveren WCG, Weiss Solís DY, Hébrant A, Detours V, Dumont JE \& Maenhaut C 2009 Human cancer cell lines: experimental models for cancer cells in situ? For cancer stem cells? Biochimica et Biophysica Acta 1795 92-103.

Studer H, Kohler H \& Búrgi H 1974 Iodine deficiency. In Handbook of Physiology (Section 7), vol 3, pp 303-328.

Takano T 2004 Fetal cell carcinogenesis of the thyroid: a hypothesis for better understanding of gene expression profile and genomic alteration in thyroid carcinoma. Endocrine Journal 51 509-515. (doi:10.1507/endocrj.51.509)

Takano T 2007 Fetal cell carcinogenesis of the thyroid: theory and practice. Seminars in Cancer Biology 17 233-240. (doi:10.1016/j.semcancer.2006. 02.001)

Tanaka M, Itoh T, Tanimizu N \& Miyajima A 2011 Liver stem/progenitor cells: their characteristics and regulatory mechanism. Journal of Biochemistry 149 231-239. (doi:10.1093/jb/mvr001)
Thomas T, Nowka K, Lan L \& Derwahl M 2006 Expression of endoderm stem cell markers: evidence for the presence of adult stem cells in human thyroid glands. Thyroid 16 537-544. (doi:10.1089/thy.2006.16.537)

Thomas D, Friedman S \& Lin RY 2008 Thyroid stem cells: lessons from normal development and thyroid cancer. Endocrine-Related Cancer 15 51-58. (doi:10.1677/ERC-07-0210)

Todaro M, Iovino F, Eterno V, Cammareri P, Gambara G, Espina V, Gulotta G, Dieli F, Giordano S, De Maria R et al. 2010 Tumorigenic and metastatic activity of human thyroid cancer stem cells. Cancer Research 70 8874-8885. (doi:10.1158/0008-5472.CAN-10-1994)

Tsai RY \& Meng L 2009 Nucleostemin: a latecomer with new tricks. International Journal of Biochemistry \& Cell Biology 41 2122-2124. (doi:10.1016/j.biocel.2009.05.020)

Wicha MS, Liu S \& Dontu G 2006 Cancer stem cells: an old idea - a paradigm shift. Cancer Research 66 1883-1890. (doi:10.1158/0008-5472.CAN-053153)

Williams ED 1995 Mechanisms and pathogenesis of thyroid cancer in animals and man. Mutational Research 333 123-129. (doi:10.1016/00275107(95)00138-7)

Wynford-Thomas D, Stringer BMJ \& Williams ED 1982 Goitrogen-induced thyroid growth in the rat: a quantitative morphometric study. Journal of Endocrinology 94 131-140. (doi:10.1677/joe.0.0940131)

Yen T-H \& Wright NA 2006 The gastrointestinal tract stem cell niche. Stem Cell Reviews 2 203-212. (doi:10.1007/s12015-006-0048-1)

Zhang C, Ye X, Zhang H, Ding M \& Deng H 2007 GATA factors induce mouse embryonic stem cell differentiation toward extraembryonic endoderm. Stem Cells Development 16 605-613. (doi:10.1089/scd.2006. 0077)

Zheng X, Cui D, Xu S, Brabant G \& Derwahl M 2010 Doxorubicin fails to eradicate cancer stem cells derived from anaplastic thyroid carcinoma cells: characterisation of resistant cells. International Journal of Oncology 37 307-315. (doi:10.3892/ijo_00000746)

Zhou S, Schutz JD, Bunting KD, Colapietro AM, Sampath J, Morris JJ, Lagutina I, Grosveld GC, Osawa M, Nakauchi H et al. 2001 The ABC transporter BCRP1/ABCG2 is expressed in a wide variety of stem cells and is a molecular determinant of the side-population phenotype. Nature Medicine 7 1028-1034. (doi:10.1038/nm0901-1028)

Zhu W, Hai T, Ye L \& Cote GJ 2010 Medullary thyroid carcinoma cell lines contain a self-renewing $\mathrm{CD} 133^{+}$population that is dependent on ret proto-oncogene activity. Journal of Clinical Endocrinology and Metabolism 95 439-444. (doi:10.1210/jc.2009-1485)

Zito G, Richiusa P, Bommarito A, Carissimi E, Russo L, Coppola A, Zerilli M, Rodolico V, Criscimanna A, Amato M et al. 2008 In vitro identification and characterisation of CD133(pos) cancer stem-like cells in anaplastic thyroid carcinoma cell lines. PLoS ONE 3 e3544. (doi:10.1371/journal. pone.0003544)

Received in final form 24 September 2011 Accepted 24 October 2011 Made available online as an Accepted Preprint 25 October 2011 